\title{
An Adaptive Web-based Learning Module for the Problem-based Application of Remote Sensing in Schools - Prototype within an Educational Design Research Study
}

\author{
Vera Fuchsgruber ${ }^{1}$ and Alexander Siegmund 1,2 \\ 1 Heidelberg University of Education, Germany \\ 2 Heidelberg Center for the Environment, Germany
}

\begin{abstract}
The learning module "Drought in California" presented here is part of an adaptive webbased learning platform developed in the framework of the Space4Geography project, funded by the German Aerospace Centre (Space Administration). The project seeks to facilitate the application of satellite images in schools and to enable students to work with original remote-sensing data on geographic questions. The development process of the module was informed scientifically by Educational Design Research. The research approach involves practitioners and scientists in the development process and aims to (1) ensure the practice-oriented, motivating and learning-efficient character of the learning module, and (2) contribute to educational theory in the field of remote-sensing education. This paper presents the prototype of the adaptive learning module, the development of which was based on results from an analysis of national curricula and an online survey on requirements for a learning environment. This prototype will be evaluated and developed further in several test cycles before being implemented in school practice.
\end{abstract}

\section{Keywords:}

remote-sensing education, adaptive learning platform, satellite images, Educational Design Research, design-based research

\section{Background and objectives}

Remote sensing represents a key technology in the 21st century. Along with increasing availability of earth observation data, sensor systems show major improvements regarding spatial, spectral and temporal resolutions (Jensen, 2007). In students' everyday lives and in schools, the presence of satellite images has also increased in recent decades (Pingold, 2013; Ditter et al., 2012b; Siegmund, 2010; Voss, 2011; Gryl et al., 2014), and the growing importance of spatial information can be observed globally (Kerski et al., 2012). Using basic subject-specific methods, remote sensing holds great educational potential for geography and 
interdisciplinary lessons (Voss, 2011). The competences to interpret and analyse satellite images are represented in Germany's national education standards and a growing number of federal curricula (DGfG, 2007; Siegmund, 2010; KMK, 2015).

Generally speaking, the application of satellite images in (geography) classes is increasing with the availability of teaching materials such as a satellite image atlas (Diercke, 2010). From an international perspective, a typical application of satellite images in geography lessons is the use of the virtual globe Google Earth (Liiber et al., 2014; Lázaro y Torres et al,. 2008; Hassenpflug, 2012). Although there are a few exceptions (Goetzke et al., 2014; Rienow et al., 2015), the practical implementation hardly ever goes beyond the visual interpretation of truecolour printed images, neglecting the high information content of false-colour images and further digital image analysis (Ditter, 2013; Pingold, 2013; Kestler, 2015). One reason is the current representation of remote sensing in the standard German literature for geography education - in many books, the use of satellite images is included in the method, but when it comes to their practical application, only methods for their visual interpretation are described (Hassenpflug, 2012; Kollar, 2012; Krautter, 2015; Kestler, 2015; Rinschede, 2007). In addition to this, the complexity of remote sensing may lead to time-consuming lesson preparation when teachers lack the relevant expert knowledge (Ditter et al., 2012b). Nonetheless, research findings indicate high interest and motivation as well as learning efficacy for students working with satellite images (Ditter, 2013; Siegmund, 2010). Therefore, holistic solutions are required offering teachers an easy-to-use and practical solution for the application of satellite images in their lessons.

Against this background, an adaptive learning environment for the problem-based, interactive application of original satellite images is being developed within the framework of the Space4Geography project, funded by the German Aerospace Centre (Space Administration). The platform provides ten learning modules, enabling students to work on up-to-date geography topics applying remote-sensing methods. In this paper, the prototype of the learning module "Drought in California" is presented, with a focus on the educational concept. The development is accompanied by an Educational Design Research project (see section 2.1).

\section{Research approach, methods and results}

\section{Educational Design Research: characteristics and implementation}

Educational Design Research - also known as Design-based Research (Wang \& Hanafin, 2005; Bakker, 2004) - aims at bridging the gap between school practice, pedagogical theory and empirical research, and is increasingly applied in geography education research (Feulner et al., 2015; Plomp, 2007). The main characteristics of the approach are: (a) the involvement of users and experts in the whole development and research process; (b) several iterations of testing, evaluation and further development; the evaluation implies qualitative and quantitative research methods; (c) two objectives in this specific project: to develop a learning module that can be easily implemented in school practice, and to contribute to educational theories, especially in remote-sensing education. 
Following Plomp (2007), this study comprises four phases for the development of the learning module. First, the problem is defined by analysis of the current state of research as seen in the literature (see section 1), and experts and practitioners are involved via an online survey. A nationwide analysis of curricula is also performed in order to ensure the learning module's applicability across Germany's federal states. In the second phase, a prototype of the adaptive learning module is developed, taking into account existing design principles (educational theories) and the results of the survey. As a third step, the prototype will be tested in several cycles by experts, teachers and students, with a view to the implementation of the final version of the module in school practice. The findings made during the development and evaluation process will be documented and will contribute new theories to the research field of remote-sensing education. Sections 2.2 and 2.3 present outcomes from the first phase (curricula analysis and online survey). The educational concept of the learning module prototype, derived from the analysis and survey, is described in section 3.

\section{Nationwide Curricula Analysis for Geography}

For easy implementation in geography classes, the learning module has to cover one or more topics of the different state curricula. Germany has a different curriculum in each of the 16 federal states, which vary in terms of extent, structure and freedom of prioritization. A nationwide curricula analysis was carried out, categorizing regional and thematic specifications, to produce an overview that allows the comparison of all German curricula for the school type Gymnasium (secondary school). All thematic entries of the 16 curricula were listed in one database. On the basis of the database, categories for topics and regions were developed in collaboration with experts in teaching methodology and science. The categories were compared with the standard literature in geography (e.g. Gebhardt et al., 2012) to ensure that all key geography topics were covered. They were also compared with categories from other empirical studies (Reuschenbach, 2007; Hemmer \& Hemmer, 2010). Two people allocated categories to the entries listed in order to ensure the reliability and validity of the results. The database is available online and can be searched and used on $<$ www.rgeo.de/bpa $>$. It offers two applications: existing learning materials can be assigned to curricula content; it can also, as in this study, be used to define topics and help identify geographic regions of nationwide curricular relevance when developing learning materials.

The database does not allow a comparison of the absolute frequency of entries between states, as a lower number of entries does not imply a lower weighting of a topic or region. Therefore, relative frequencies were calculated within each state before comparing results for the whole analysis. Figure 1 gives an overview of the thematic categories and their relative importance within the different grade levels. 


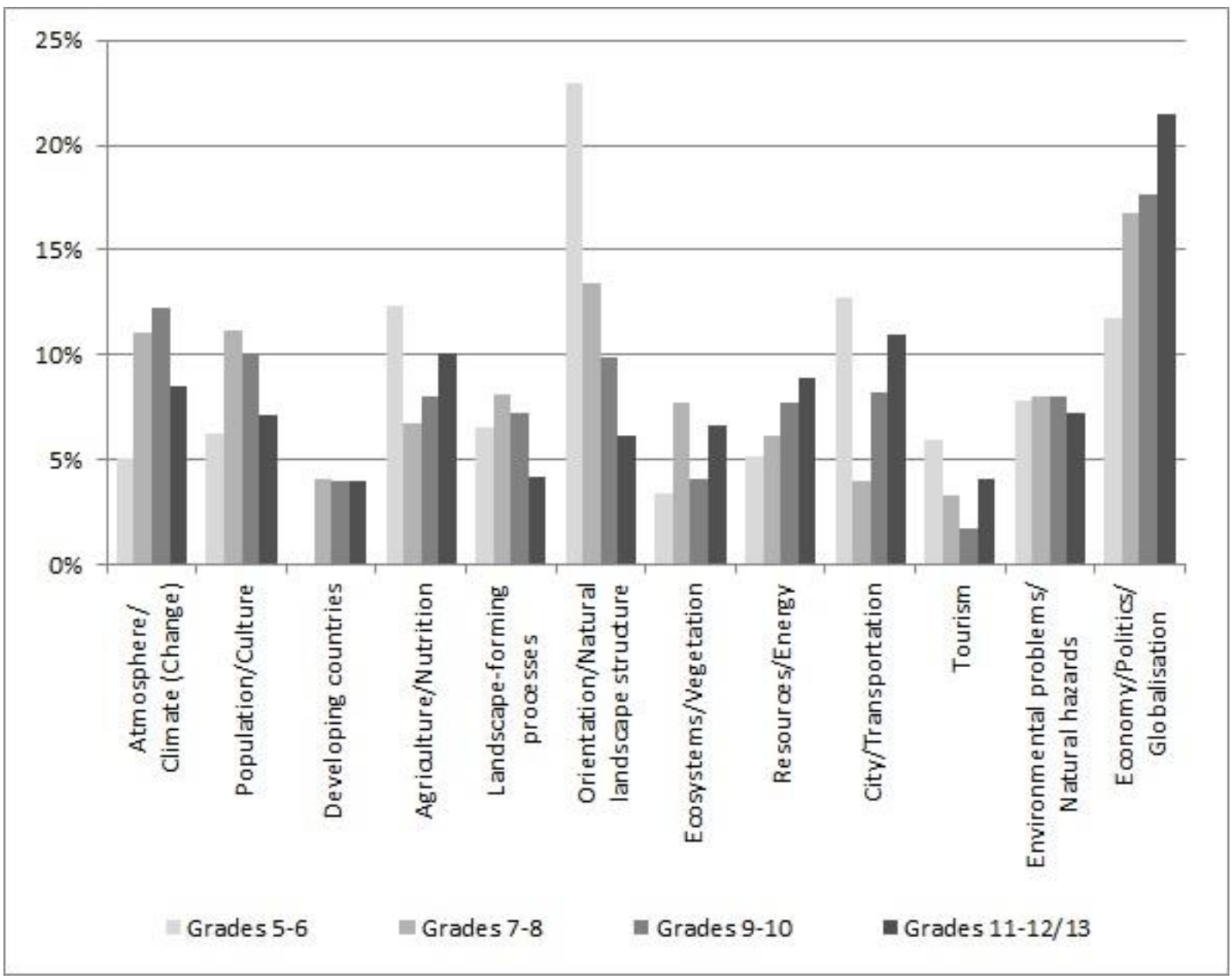

Figure 1: Average relative frequency [\%] of thematic categories in state curricula for geography in German Secondary Schools

Most of the categories show significantly higher representation in certain grade levels. For example, the category "Orientation/natural landscape structure" represents the main topic for grades 5-6, with $22.9 \%$, becoming less important in the context of later grades. "Economy/Politics/Globalization" as a theme receives the most coverage overall, with a relative frequency that rises to $21.5 \%$ in the final years of school.

\section{Online Survey on requirements of users and experts}

In order to identify crucial conceptual, educational, scientific and technical components of the learning module, an online survey was conducted. Participants included scientific experts in remote sensing and geography education, as well as potential users represented by teachers and students. The survey was therefore designed to be answered by both adults and students from grade 7 upwards and worded accordingly. To maximize the number of participants, the survey was designed to be completed in 10 minutes (Moosbrugger \& Kelava 2012). The main part of the survey consisted of four sections, each comprising five to six questions. The 
sections were (a) topic of the learning module, (b) satellite images within the learning module, (c) technical aspects of the learning platform, and (d) conception of the learning platform. The participants ranked properties within these sections on a five-point Likert scale ranging from "not important" to "very important", including the option "I don't know". Demographic variables as well as experiences in remote sensing were covered in the second part of the survey.

The survey was pre-tested with first-year university students and revised. The final version of the survey was responded to by a total of 56 people: 16 students aged 12 to 15,4 teachers, 21 scientists, and 15 people who are teachers and scientists. The adults' ages ranged from 25 to 67. Except for the group of students, the majority of participants had basic to advanced experience with satellite images. Because of the number of participants, descriptive statistics were applied to analyse the results. The key outcomes for the four sections are presented below and will be discussed in greater detail in section 3 .

The criterion "The topic is up-to-date" in section (a) was rated as the most important by 64 $\%$ of the respondents. Least important was the fact that the topic is represented in schoolbooks. In section (b), concerning the satellite images within the learning module, "viewing of satellite images" was rated most important, and information on the imageacquisition techniques was rated least important. Concerning the technical aspects of the platform in section (c), a clear, modern layout and design are most important for the users, while having a user account appears to be least important. Regarding the concept of the platform, section (d), most important is that the geographic question is the central point of the learning module, rather than theory on satellite images. Looking at the question on ludic elements, the difference between student and expert answers is very high: 10 of 15 students stated it was very important, while the majority of experts considered it less important.

\section{Educational Concept of the learning module "Drought in California"}

The learning module on "Drought in California" was conceptualized and developed (see Figure 2) based on the findings outlined in sections 2.2 and 2.3 and on existing theories from education and remote-sensing didactics. The core of the learning module comprises practical tasks using original satellite data (here: RapidEye images) to work on an overarching geographical question. Problem and activity orientation for the application of satellite images in the classroom are suggested in several publications (Michel \& Voss, 2013; Ditter et al., 2012b; Krautter, 2015; Kestler, 2015). The learning module consists of several knowledge units featuring multimedia information (text, pictures, animations, videos). Learning success is assessed via interactive tasks which encourage students to reflect on the information presented and on how to transfer their knowledge to new contexts (Reinmann \& Mandl, 2006). The score they achieve serves as the main criterion for determining adaptive learning paths. 


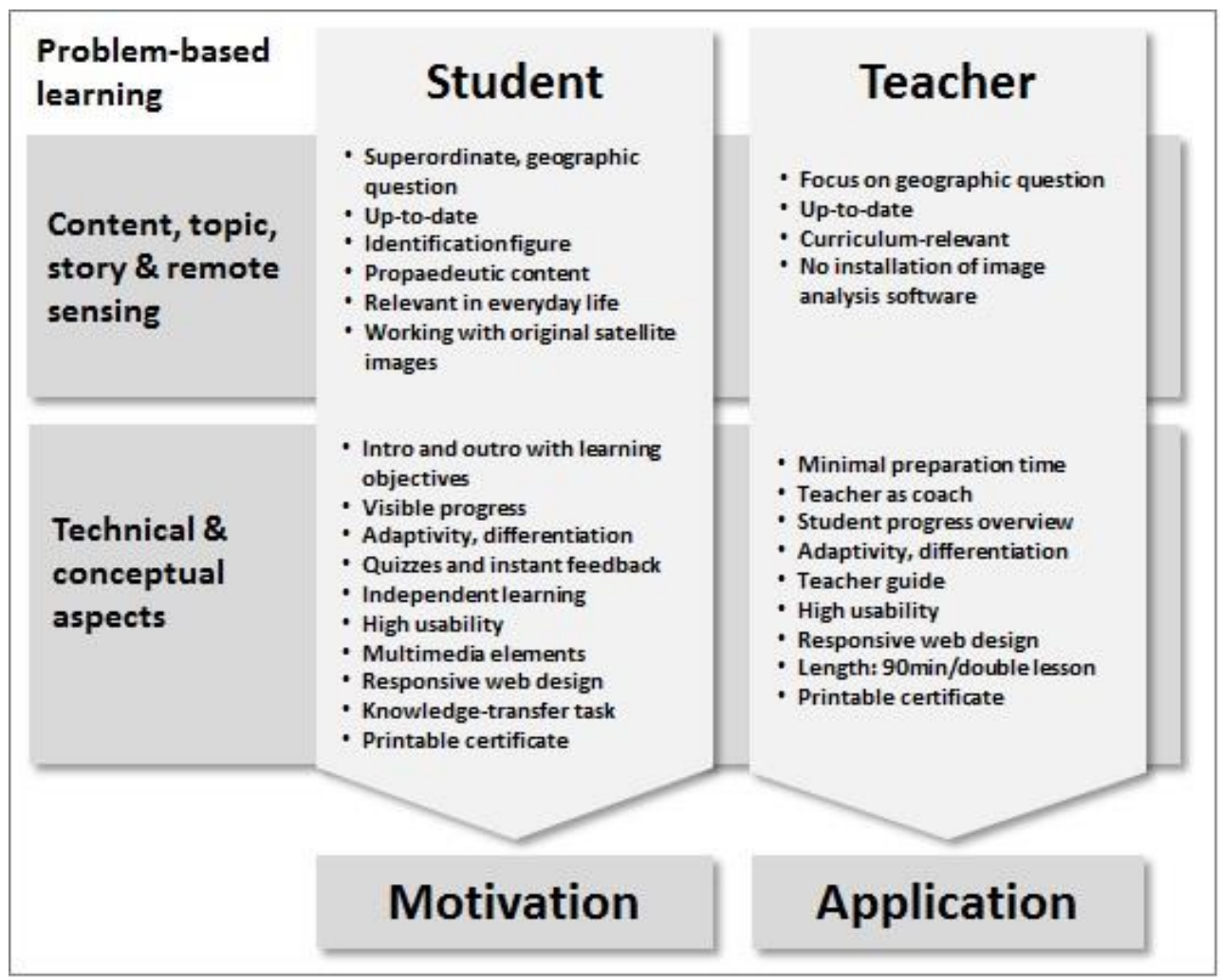

Figure 2: Educational concept of the learning module

In defining a topic for the learning module, various aspects have to be considered. Of these, teachers and scientists rated up-to-dateness as the most important (see section 2.3). School practitioners also attach importance to the presence of the topic in school curricula. For the application of satellite images along with possible propaedeutic applications, data availability and methodological possibilities have to be taken into account. As an example of case-based learning within problem-based learning (Otto \& Schuler, 2012; Felzmann, 2013), the drought in California since 2013 was chosen in order to show how satellite images help to understand the extent of the drought. Since 2013, the problem has been discussed in public media and is therefore in the student's living environment. This environmental catastrophe has also been the subject of investigation by scientists (Seager et al., 2014). In school curricula, the topic is covered in three of the categories shown in Figure 1: agriculture (in California, USA), natural hazards (drought), and climate (causes of the drought). These categories occur in 11 of the 16 federal curricula in Germany. Northern America or the USA is also the favourite region in geography lessons for students, as a study on student interests in geographical topics and regions show (Hemmer \& Hemmer, 2010).

Motivating students to work with satellite images is one of the key goals, along with successful learning outcomes. The motivation of students is addressed by several characteristics of the module. The design is user-friendly and features high usability, 
including a modern, responsive web design, which was ranked as "fairly important" or "very important" by $82 \%$ of the participants in the online survey. To give students an overview of what they can expect, a summary of the content is given in the first knowledge unit.

Figure 3 shows the first knowledge unit of the "California Drought" module featuring basic information on learning goals and a short introductory video. The information outlined in the summary is recapitulated in the last knowledge unit and on a printable certificate which is available after completing the module. The certificate includes the student's name, the topic of the module, details of its content, and results from the interactive tasks.

Progress within the learning module is constantly visible on an interactive progress bar, which allows the student to return to earlier knowledge units, giving him/her control to navigate through the module (left-hand side of the screen in Figures 3 and 4) (Peters, 2013; Wütherich, 2013). An identification figure who needs help is introduced at the start of the module (Wütherich, 2013). Here, "Journalist Jane" has to write a leading article about the drought and needs a scientific analysis and visualization. The student has to help Jane on the article and therefore needs information about the drought as well as results from satellite image analysis to visualize the extent of the drought's severity. Interactive tasks and elements such as videos encourage students to gather information in an active manner, to think about the content, and to use it in new contexts. The module's design thus aims to achieve "moderate constructivism", a balance between instruction and construction (Reinmann \& Mandl, 2006).

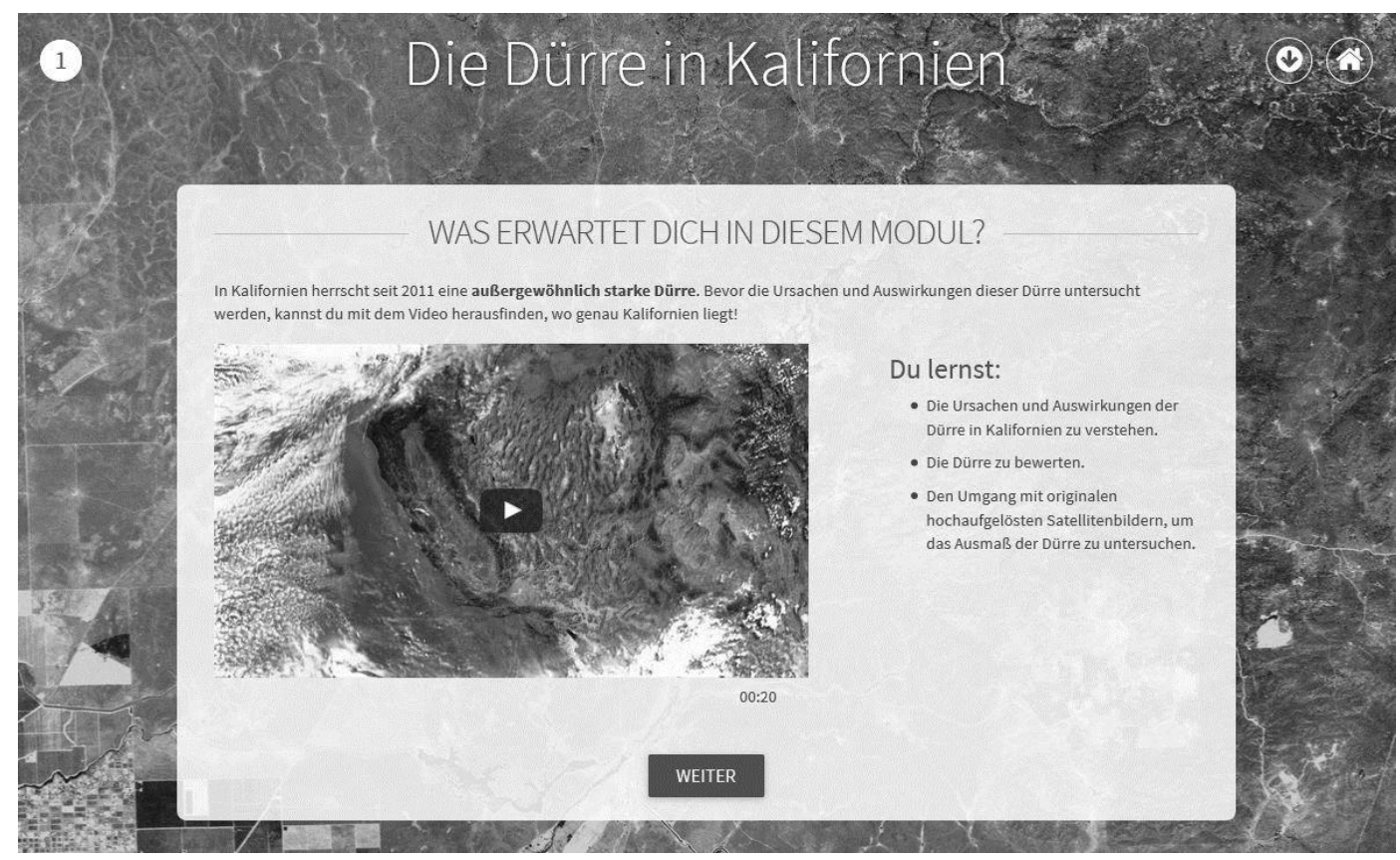

Figure 3: Visual surface from the prototype of the adaptive learning module "Drought in California" 
To meet the requirements for differentiation in schools (Szymkowiak, 2013; Uhlenwinkel, 2008), the module allows adaptive learning paths. As each student works on the interactive tasks, their individual level of knowledge is registered, analysed and evaluated, and he/she will be given information at the appropriate level in the following knowledge units (see Figure 4). The students have three attempts to answer questions correctly and they receive instant feedback on each try (Peters, 2013). Test results and the students' way through the module are tracked and can be accessed by teachers. This information will also be used for evaluation and further development of the learning platform.

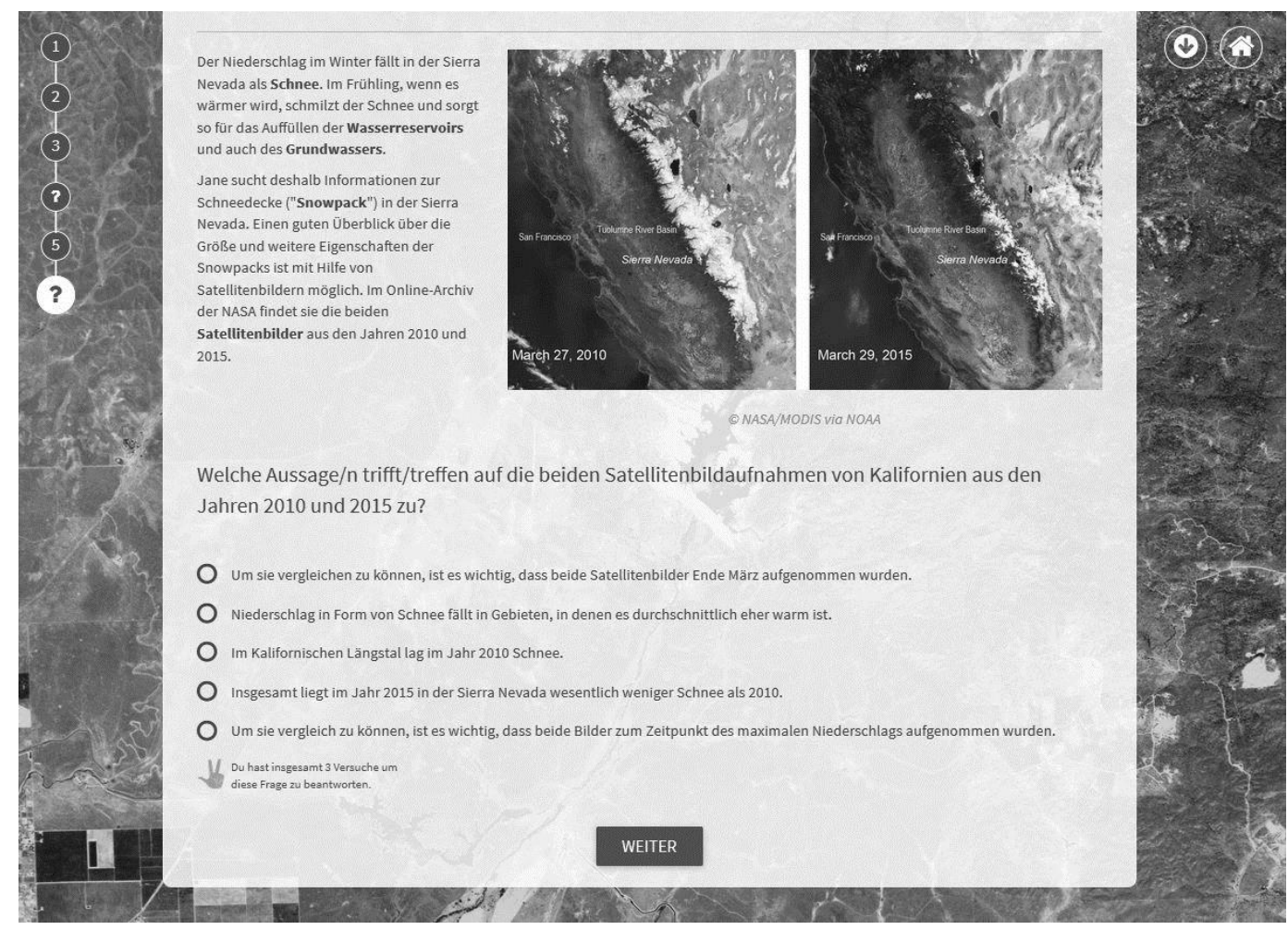

Figure 4: Interactive task (multiple-choice question): temporal comparison of satellite images of the snowpack

The core of the module is independent work using original satellite images. This is carried out using the web-based remote-sensing software BLIF (Ditter \& Siegmund, 2012), which was developed by the Research Group for Earth Observation (rgeo), Department of Geography at Heidelberg University of Education, and has been developed further and updated within the project Space4Geography. Though student-centred and didactically reduced, BLIF features a wide range of basic tools for importing, (pre-)processing and analysing of satellite images (Ditter et al., 2012a). The straightforward user interface and functions make it easier for the student to focus on the overarching question. The importance of ease of use was made clear in the results of the online survey, where $78 \%$ ranked it as "fairly" to "very important". For "Journalist Jane", the students perform a 
supervised classification and identify changes between two RapidEye scenes from 2011 and 2015. These tasks are adapted in terms of complexity and details in the instructions for the processing steps, depending on the student's prior performance. For example, the definition of the number and types of training classes is predefined for students with lower scores. Students with a higher score need less assistance and guidance. The competences gained in remote-sensing methods in the context of this module can be transferred to an examination of other regions dealing with droughts (Australia and Brazil), supporting the application of knowledge to new questions and areas (Otto \& Schuler, 2012).

Complementary to the motivational and conceptual aspects aimed at students is the easy implementation in schools by teachers. The learning module can be finished completely in 90 minutes, or a standard double lesson in Germany. Because the individual learner's rate of progress is tracked throughout the module, tasks and content are adjusted to allow each learner to complete the module within 90 minutes and receive their certificate. The role of the teacher changes to that of coach in cases where students have technical issues or problems of understanding (Ditter et al., 2012b). To minimize the preparation time for teachers, a teacher's guide can be downloaded. It contains information about the educational concept, details of the content, requisite information on remote sensing, and, to meet socialconstructivist guidelines (Otto \& Schuler, 2012), material for group discussions after finishing the module. The certificate can be printed to record results in analogue format. Teachers can also view students' progress and results, which allows teachers to use the completion of the learning module as homework and discuss results in class, with support from the teacher's guide.

\section{Conclusions and Future developments}

This paper presents the prototype of a learning module, developed within an Educational Design Research project, for using satellite images in the context of secondary-school geography classes. Methods and results for a curriculum analysis and an online survey were presented. On the basis of these results, an educational concept and topic for the module were defined to meet the goal of motivating students and developing a practice-oriented learning platform. The prototype will be evaluated and developed further in at least two test cycles with researchers from science and education, teachers and students. The module focuses on students' motivation and learning efficacy, as well as on practical considerations from the teacher's point of view. Markers of student motivation will be collected on two separate occasions using standardized questionnaires focusing on intrinsic motivation (Wilde et al., 2009; Gerstner, 2009): first, after the more problem-based introductory part of the module, and second, after working with original satellite images. Students will also be asked to answer general evaluation questions on the structure, content and layout/design of the module. Teachers will evaluate the learning module and will be interviewed in order to fulfil the requirements of involving practitioners and experts (teachers take both roles) (Niebert \& Gropengießer, 2014). Student interviews during the first test cycles are also being considered. Evaluations with students will be carried out in cooperation with the DLR_School_Labs in Oberpfaffenhofen, Germany, and the GIS-Station at the Department of Geography, Heidelberg University of Education. 


\section{Acknowledgements}

The project Space4Geography is funded by the German Aerospace Centre (Space Administration) with resources from the Federal Ministry for Economic Affairs and Energy.

\section{References}

Bakker, A. (2004): Design research in statistics education. On symbolizing and computer tools. Utrecht University.

DGfG (2007): Bildungsstandards im Fach Geographie für den Mittleren Schulabschluss - mit Aufgabenbeispielen. Deutsche Gesellschaft für Geographie.

Diercke (2010): Die Welt im Wandel. Satellitenbildatlas. With assistance of M. Eisl, T. Michael. Westermann, Braunschweig.

Ditter, R. (2013): Die Wirksamkeit digitaler Lernwege in der Fernerkundung. Eine empirische Untersuchung zu Lernmotivation und Selbstkonzept bei Schülerinnen und Schülern der Sekundarstufe. Heidelberg University of Education.

Ditter, R.; Kollar, I.; Siegmund, A.; Siegmund, A. (2012a): Angewandte geographische Fernerkundung. Teil 1: Potenziale des Satellitenbildeinsatzes im Unterricht - Ergebnisse aktueller fachdidaktischer Forschung. In Geographie und Schule 34 (198), pp. 48-49.

Ditter, R.; Michel, U.; Siegmund, A. (2012b): Neue Medien - Möglichkeiten und Grenzen. In JohannBernhard Haversath (Ed.): Geographiedidaktik. Westermann.

Ditter, R.; Siegmund, A. (2012): Der Einsatz von "BliF" in einem zeitgemäßen Geographieunterricht oder - ein (Satelliten-)Bild sagt mehr als 1024 Worte. In Armin Hüttermann (Ed.): Räumliche Orientierung. Karten und Geoinformation im Unterricht. Braunschweig, Westermann (Geographiedidaktische Forschungen, 49).

Felzmann, D. (2013): Problemorientierter/-lösender Unterricht. In Dieter Böhn, Gabriele Obermaier (Eds.): Wörterbuch der Geographiedidaktik. Begriffe von A-Z. Braunschweig, Westermann.

Feulner, B.; Ohl, U.; Hörmann, I. (2015): Design-Based Research - ein Ansatz empirischer Forschung und seine Potenziale für die Geographiedidaktik. In Zeitschrift für Geographiedidaktik (3).

Gebhardt, H.; Glaser, R.; Radtke, U.; Reuber, P. (Eds.) (2012): Geographie. Physische Geographie und Humangeographie. Springer.

Gerstner, S. (2009): Eine empirische Studie zum Einsatz von schülerzentrierten Unterrichtsmethoden im Natur- und Technik-Unterricht zum Thema "Wasser - Grundlage des Lebens", Universität Bayreuth.

Goetzke, R.; Hodam, H.; Rienow, A.; Voss, K. (2014): Floods: Dealing with a Constant Threat. In Thomas Jekel, Eric Sanchez, Inga Gryl, Caroline Jouneau-Sion, John Lyon (Eds.): Learning and Teaching With Geomedia, Cambridge Scholars Publishing, pp. 90-101.

Gryl, I.; Sanchez, E.; Jekel, T.; Jouneau-Sion, C.; Lyon, J.; Höhnle, S. (2014): Educational Uses of Geomedia. In Thomas Jekel, Eric Sanchez, Inga Gryl, Caroline Jouneau-Sion, John Lyon (Eds.): Learning and Teaching With Geomedia, Cambridge Scholars Publishing, pp. 29-41.

Hassenpflug, W. (2012): Verstehen, was wir sehen - Google Earth und Co machen möglich, wovon abgetretene Geo-Didaktiker träumen. In Armin Hüttermann (Ed.): Räumliche Orientierung. Karten und Geoinformation im Unterricht. Braunschweig, Westermann (Geographiedidaktische Forschungen, 49).

Hemmer, I.; Hemmer, M. (2010): Interesse von Schülern an einzelnen Themen, Regionen und Arbeitsweisen des Geographieunterrichts - ein Vergleich zweier empirischer Studien aus dem Jahr 1995 und 2005. In Ingrid Hemmer, Michael Hemmer (Eds.): Schülerinteresse an Themen, Regionen und Arbeitsweisen des Geographieunterrichts. Ergebnisse der empirischen Forschung 
und deren Konsequenzen für die Unterrichtspraxis, Hochschulverband für Geographie und ihre Didaktik e.V., pp. 65-145.

Jensen, John R. (2007): Remote sensing of the environment. An earth resource perspective. Pearson Prentice Hall, Upper Saddle River, NJ (Prentice Hall series in geographic information science).

Kerski, J. J.; Milson, J. A.; Demirci, A. (2012): Synthesis: The Future Landscape of GIS in Secondary School. In J. Andrew Milson, Ali Demirci, Joseph James Kerski (Eds.): International Perspectives on Teaching and Learning with GIS in Secondary Schools. New York, Springer, pp. 315-326.

Kestler, Franz (2015): Einführung in die Didaktik des Geographieunterrichts: Grundlagen der Geographiedidaktik und ihrer Bezugswissenschaften. Julius Klinkhardt, Bad Heilbrunn.

KMK (2015): Bildungspläne/Lehrpläne der Länder im Internet. Kultusministerkonferenz. Available online at http://www.kmk.org/dokumentation/lehrplaene/uebersicht-lehrplaene.html, checked on $1 / 13 / 2016$.

Kollar, I. (2012): Die Satellitenbild-Lesekompetenz. Empirische Überprüfung eines theoriegeleiteten Kompetenzstrukturmodells für das „Lesen“ von Satellitenbildern. Heidelberg University of Education.

Krautter, Y. (2015): Medien im Geographieunterricht nach lernförderlichen Kriterien auswählen. In Sybille Reinfried, Hartwig Haubrich (Eds.): Geographie unterrichten lernen. Die Didaktik der Geographie. Berlin, Cornelsen.

Lázaro y Torres, M. L. de; González, M. J.; Lozano de San Cleto, María José (2008): Google Earth and ArcGIS Explorer in Geographical Education. In Thomas Jekel, Alfons Koller, Karl Donert (Eds.): Learning with Geoinformation III. Heidelberg, Wichmann, pp. 97-105.

Liiber, Ü.; Roosaare, J.; Rootsmaa, V. (2014): Learning about World Agriculture with Google Earth and Faostat. In Thomas Jekel, Eric Sanchez, Inga Gryl, Caroline Jouneau-Sion, John Lyon (Eds.): Learning and Teaching With Geomedia, Cambridge Scholars Publishing, pp. 70-79.

Michel, U.; Voss, K. (2013): Fernerkundung. In Dieter Böhn, Gabriele Obermaier (Eds.): Wörterbuch der Geographiedidaktik. Begriffe von A-Z. Braunschweig, Westermann.

Moosbrugger, H.; Kelava, A. (2012): Qualitätsanforderungen an einen psychologischen Test (Testgütekriterien). In H. Moosbrugger, A. Kelava (Eds.): Thesttheorie und Fragebogenkonstruktion. Berlin, Heidelberg, Springer.

Niebert, K.; Gropengießer, H. (2014): Leitfadengestützte Interviews. In Dirk Krüger, Ilka Parchmann, Horst Schecker (Ed.): Methoden in der naturwissenschaftsdidaktischen Sozialforschung. Berlin, Heidelberg, Springer.

Otto, K.-H.; Schuler, S. (2012): Pädagogisch-psychologische Ansätze. In Johann-Bernhard Haversath (Ed.): Geographiedidaktik, Westermann.

Peters, D. (2013): Interface Design for Learning. New Riders.

Pingold, M. (2013): Luft- und Satellitenbilder. In Dieter Böhn, Gabriele Obermaier (Eds.): Wörterbuch der Geographiedidaktik. Begriffe von A-Z. Braunschweig, Westermann.

Plomp, T. (2007): Educational Design Research: an Introduction. In Tjeerd Plomp, Nienke Nieveen (Eds.): An Introduction Educational Design Research. SLO Netherlands Institute for curriculum development, Enschede.

Reinmann, G.; Mandl, H. (2006): Unterrichten und Lernumgebungen gestalten. In A. Krapp, M. Prenzel, B. Weidenmann (Eds.): Pädagogische Psychologie. Ein Lehrbuch. Weinheim, Beltz.

Reuschenbach, Monika (2007): Entwicklung und Realisierung eines Konzeptes zur verstärkten Integration der Fernerkundung, insbesondere von Luft- und Satellitenbildern in den Geographieunterricht. Universität Zürich.

Rienow, A.; Hodam, H.; Selg, F.; Menz, G. (2015): Columbus Eye: Interactive Earth Observation from the ISS in Class Rooms. In Journal for Geographic Information Science (1), pp. 349-354.

Rinschede, Gisbert (2007): Geographiedidaktik. Schöningh UTB. 
Seager, R.; Hoerling, M.; Schubert, S.; Wang, H.; Lyon, B.; Kumar, A. et al. (2014): Causes and Predictability of the 2011-2014 California Drought. Assessment Report. Available online at http://cpo.noaa.gov/MAPP/californiadroughtreport, checked on 1/27/2015.

Siegmund, A. (2010): Satellitenbilder im Unterricht - eine Ländervergleichsstudie zur Ableitung fernerkundungsdidaktischer Grundsätze. Pädagogische Hochschule Heidelberg, Heidelberg. Available online at http://opus.bsz-bw.de/phhd/frontdoor.php?source_opus $=7524 \& l a=$ de, checked on $1 / 15 / 2016$.

Szymkowiak, A. (2013): Binnendifferenzierung. In Dieter Böhn, Gabriele Obermaier (Eds.): Wörterbuch der Geographiedidaktik. Begriffe von A-Z. Braunschweig, Westermann.

Uhlenwinkel, A. (2008): Binnendifferenzierung im Geographieunterricht. In Praxis Geographie (3).

Voss, K. (2011): Fernerkundung - ein Thema für den modernen Geographieunterricht. In Praxis Geographie (11), pp. 14-17.

Wang, F.; Hanafin, M. J. (2005): Design-Based Research and Technology-Enhanced Learning Environments. In Educational Technology Research \& Developtment (Vol. 53, No. 4), pp. 5-23.

Wilde, M.; Bätz, K.; Kovaleva, A.; Urhahne, D. (2009): Überprüfung einer Kurzskala intrinsischer Motivation (KIM). In Zeitschrift für Didaktik der Naturwissenschaften 15.

Wütherich, C. (2013): Methodik des Geographieunterrichts. Westermann, Braunschweig. 